\title{
PENGEMBANGAN SISTEM INFORMASI PENYAKIT TIDAK MENULAR (PTM) BERBASIS TEKNOLOGI INFORMASI
}

\author{
Hesti Kurniasih $^{1)}$, Katrin Dwi Purnanti ${ }^{2)}$, Rangga Atmajaya ${ }^{3)}$ \\ 1,2Jurusan Kebidanan, Poltekkes Kemenkes Semarang, Indonesia \\ ${ }^{3}$ Szkoła Gtówna Gospodarstwa Wiejskiego /SGGW, Warsaw University of Life Sciences, Polandia \\ ${ }^{1,2}$ Jln. Raya Baturraden KM 12, Banyumas Jawa Tengah \\ ${ }^{3}$ Nowoursynowska 166, 02-787 Warsaw, Poland \\ Email: ${ }^{1}$ hesti.kurniasih@poltekkes-smg.ac.id, ${ }^{2}$ katrindwipurnanti@gmail.com, ${ }^{3}$ ranggaatmajaya@gmail.com
}

\begin{abstract}
The increase in deaths from Non-Communicable Diseases (NCD) is a serious threat to public health today. According to a survey of 10 people with PTM as many as 7 people do not realize they have PTM, so they are late in getting treatment which results in complications. costs and dependence of PTM sufferers on their families and surrounding communities. This long-lasting disease requires a large amount of money in the treatment and care process. Non-communicable disease $(N C D)$ is one of the health problems in the community which is increasing every year, and is the biggest contributor to global mortality. Most (80\%) NCDs occur in developing countries, including Indonesia. According to the Global Status Report on Non-Communicable Diseases, PTM can occur due to lack of physical activity, smoking, ineffective eating patterns, as a result can cause an increase in pressure, an increase in blood sugar, and an increase in blood fat. If this increase is not prevented, it will worsen and cause chronic diseases such as hypertension, diabetes, cholesterol, dyslipidemia and obesity. The development of this non-communicable information system is expected to help the community to observe health conditions. The public can use this system either through computers, mobile phones or other devices connected to the internet. The use of this application is very practical because users can access it anywhere and anytime.
\end{abstract}

Keyword: website; information Systems; non-communicable diseases; public; health workers

\begin{abstract}
Abstrak
Peningkatan kematian akibat Penyakit Tidak Menular (PTM) menjadi ancaman serius kesehatan masyarakat dewasa ini.Menurut survey dari 10 orang penyandang PTM sebanyak 7 orang tidak menyadari dirinya mengidap PTM, sehingga terlambat dalam mendapatkan penanganan yang mengakibatkan terjadinya komplikasi.Kondisi ini tentu berdampak pada semakin tingginya biaya dan ketergantungan pengidap PTM pada keluarga dan masyarakat disekitarnya. Penyakit yang penyembuhannya lama ini membutuhkan biaya yang besar dalam proses pengobatan dan perawatannya. Penyakit tidak menular (PTM) merupakan salah satu masalah kesehatan di masyarakat yang setiap tahunnya mengalami peningkatan, dan menjadi penyumbang terbesar kejadian kematian global. Sebagian besar (80\%) PTM terjadi di negara berkembang, termasuk Indonesia. Menurut Global Status Report on Non Communicable Diseases, PTM dapat terjadi akibat kurangnya aktivitas fisik, merokok, pola makan yang tidak efektif, akibatnya dapat menyebabkan kenaikan tekanan, kenaikan gula darah, dan peningkatan lemak darah. Apabila kenaikan tersebut tidak dicegah, akan memperparah dan menyebabkan penyakit yang kronis seperti hipertensi, diabetes, kolesterol, displidemia dan obesitas. Pengembangan system informasi tidak menular ini diharapkan dapat membantu masyarakat untuk mengamati kondisi kesehatan. Masyarakat dapat menggunakan system ini baik melalui computer, handphone maupaun perangkat lain yang terhubung dengan internet. Penggunaan aplikasi ini sangat praktis karena pengguna dapat mengakses dimana saja dan kapan saja
\end{abstract}

Kata Kunci: website; sistem informasi; penyakit tidak menular; masyarakat; tenaga kesehatan

\section{Pendahuluan}

Kesehatan merupakan aset yang sangat penting untuk membentuk generasi manusia yang mampu menatap amsa depan dengan penuh antusiasme, energi dan spirit yang mengarah kepada kemajuan dan kesuksesan. Kesehatan merupakan salah satu bagian yang sangat penting bagi setiap orang. Masalah kesehatan masyarakat adalah masalah kompleks yang merupakan resultance dari berbagai masalah lingkungan yang bersifat alamiah maupun masalah buatan manusia, sosial budaya, perilaku, populasi penduduk, genetika dan sebagainya. Lingkungan menyediakan sumber daya alam dimana manusia yang hidp bermasyarakat mengelola sumber daya tersebut sedemikian rupa berdasarkan kemampuan dan pengetahuan yang diwarisinya secara turun menurun.[1]

Manusia dengan pengetahuannya dapat mengubah, mempengaruhi dan membentuk lingkungan yang dapat 
memberikan sumber kehdiupan sesuai dengan apa yang dibutuhkan. Seringkali manusia mendayagunakan alam lingkungannya dan berusaha melakukannya dengan cermat dan penuh kehati-hatian, namun di sisi lain manusia kadang tidak menyadari bahwa lingkungan dapat menyebabkan sumber penyakit bagi mereka.[1]

Pola kejadian penyakit saat ini telah mengalami perubahan yang ditandai dengan transisi epidemologi. Perubahan pola penyakit yang semula didominasi oleh penyakit infeksi beralih pada penyakit tidak menular (PTM).Perhatian dunia terhadap penyakit tidak menular semakin meningkat seiring dengan peningkatan frekuensi kejadiannya.Dua dari sepuluh penyebab utama kematian didunia disebabkan oleh penyakit tidak menular, stroke dan penyakit jantung iskemik bahkan menajdi penyebab kedua teratas baik di Negara maju maupun berkembang. [2]

Peningkatan kematian akibat Penyakit Tidak Menular (PTM) menjadi ancaman serius kesehatan masyarakat dewasa ini. Menurut survey dari 10 orang penyandang PTM sebanyak 7 orang tidak menyadari dirinya mengidap PTM, sehingga terlambat dalam mendapatkan penanganan yang mengakibatkan terjadinya komplikasi. Kondisi ini tentu berdampak pada semakin tingginya biaya dan ketergantungan pengidap PTM pada keluarga dan masyarakat disekitarnya. Penyakit yang penyembuhannya lama ini membutuhkan biaya yang besar dalam proses pengobatan dan perawatannya.[3]

Penyakit tidak menular (PTM) merupakan salah satu masalah kesehatan di masyarakat yang setiap tahunnya mengalami peningkatan, dan menjadi penyumbang terbesar kejadian kematian global. Sebagian besar $(80 \%)$ PTM terjadi di negara berkembang, termasuk Indonesia. Menurut Global Status Report on Non Communicable Diseases, WHO (2010) PTM dapat terjadi akibat kurangnya aktivitas fisik, merokok, pola makan yang tidak efektif, akibatnya dapat menyebabkan kenaikan tekanan, kenaikan gula darah, dan peningkatan lemak darah. Apabila kenaikan tersebut tidak dicegah, akan memperparah dan menyebabkan penyakit yang kronis seperti hipertensi, diabetes, kolesterol, displidemia dan obesitas. [4]

Penyakit tidak menular telah menjadi penyebab utama kematian secara global pada saat ini (Shilton, 2013). Data WHO menunjukkan bahwa sebanyak 57 juta (63\%) angka kematian yang terjadi di dunia dan 36 juta (43\%) angka kesakitan disebabkan oleh Penyakit Tidak Menular. Global status report on NCD World Health Organization (WHO) tahun 2010 melaporkan bahwa 60\% penyebab kematian semua umur di dunia adalah karena PTM da 4\% meninggal sebelum usia 70 tahun. Seluruh kematian akibat PTM terjadi pada orang-orang berusia kurang dari 60 tahun, 29\% di Negara-negara berkembang, sedangkan di Negara-negara maju sebesar 13\% (Remais, 2012).

Penyakit tidak menular di Indonesia diklasifikasikan oleh Kemenkes melalui Ditjen P2PTM terdiri dari Jantung Koroner, Stroke, Hipertensi, Kanker Leher Rahim, Kanker Payudara, Diabetes Melitus,
Penyakit Paru Obstruktif Kronik (PPOK), Asma, Katarak. Tren penyakit tidak menular mengalami peningkatan dari tahun 2013-2019 berdasarkan Riskesdas 2018.Beban ekonomi Negara akibat penyakit Katastropik ini pun mengalami peningkata.Beban penyakit katastropik termasuk penyakit tidak menular yang ditanggung oleh JKN tahun 2014-2015 untuk kasus kanker mencapai Rp. 2.470 Triliyun.

Berdasarkan latar belakang masalah yang telah peneliti uraikan di atas, maka peneliti hendak membuat sebuah penelitian yang berjudul " Pengembangan Sistem Informasi Penyakit Tidak Menular (PTM) Berbasis Android" yang diharapkan mampu membuat orang untuk mendapatkan informasi terkait PTM lebih cepat dan tepat. Selain itu, penelitian ini diharapkan dapat membantu untuk mengamati kondisi kesehatan masyarakat.

\section{Metodologi Penelitian}

Penelitian ini merupakan metode rancang bangun yaitu kegiatan menerjemahkan hasil analisa ke dalam bentuk perangkat lunak yang kemudian menciptakan atau memperbaiki system yang sudah ada. Metode pengembangan system yang digunakan dalam rancang bangun system informasi PTM ini menggunakan model waterfall atau model sekuensial linier. Model waterfall merupakan model pengembangan perangkat lunak yang sistematik dan sekuensial yang mulai pada tingkat dan kemajuan sistem sampai pada analisis, desain, kode, test, dan pemeliharaan.

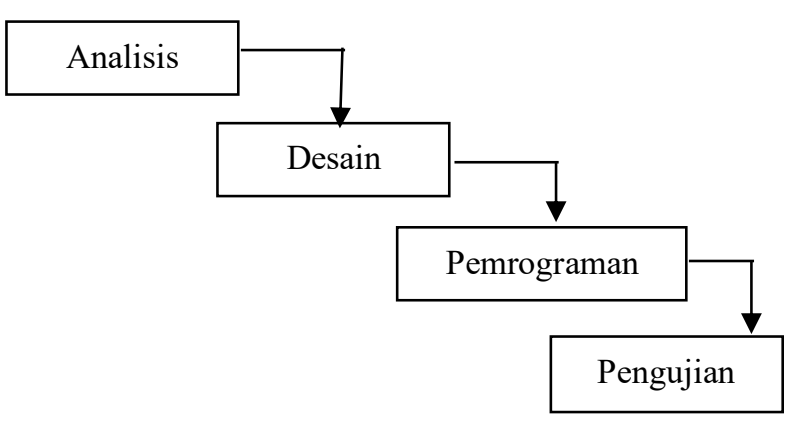

Gambar 1. Model Waterfall

Variable penelitian ini yaitu variable bebas dalam hal ini adalah biodata peserta pemeriksaan (karakteristik subyek penelitian), sedangkan data terikat yaitu model PTM dan diagnose PTM. Populasi dalam penelitian ini adalah seluruh peserta Posbindu Cerdik di wilayah Kampus 7 Poltekkes Kemenkes Semarang.

\section{Hasil dan Pembahasan}

\subsection{Hasil}

Analisa data deskriptif penelitian ini deskripsi deteksi dini penyakit tidak menular (PTM) menggunakan system informasi ruled based system. Dalam penelitian ini peneliti menggunakan system informasi Deteksi Dini Penyait Tidak Menular (SIP-TMEN) rule based system yang diharapkan dapat mengatasi permasalah dalam 
deteksi dini dan diagnose penyakit tidak menular yang selama ini masih dilakukan secara manual. SIP-TMEN dapat diakses menggunakan website browser baik melalui computer, tablet, maupun smartphone. Adapun system yang dikembangkan yaitu :

a. Menu Awal (Beranda)

Menu awal (Belanda) berisi tentang penjelasan tentang SIP-TMEN dan informasi tentang penyakit tidak menular. Di atas menu beranda terdapat menu lain yaitu registrasi pengguna dan login akun. Pengguna dapat mengakses system ini dengan cara masuk melalui laman http://sip-tmen.id/ . Menu awal dari system informasi rule based system deteksi dini penyakit tidak menular (SIP-TMEN) dapat dilihat pada gambar 1 berikut :

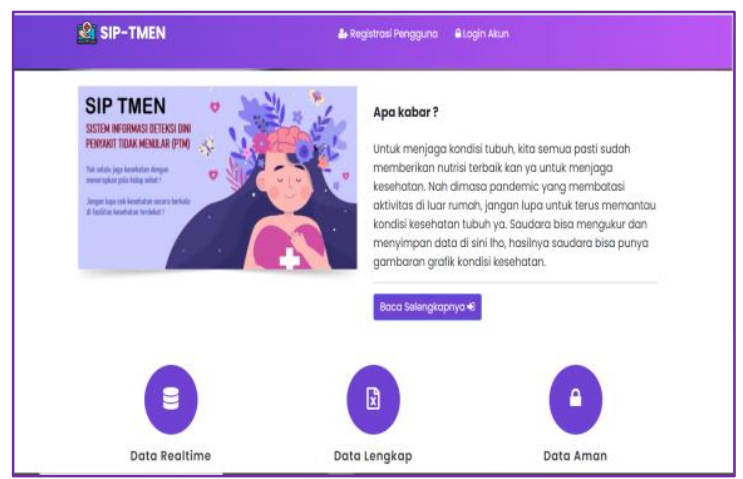

Gambar 2. Menu awal (Beranda) Deteksi Dini Penyakit Tidak Menular

\section{b. Halaman Log in}

Halaman Log in pada system informasi deteksi dini penyakit tidak menular (SIP-TMEN) seperti yang tampak pada gambar 2. digunakan untuk membatasi hak akses kepada dinas kesehatan kabupaten, kepala puskesmas dan bidan dalam hal pengoperasian system. Untuk masuk ke dalam system, admin di tingkat dinas kesehatan kabupaten/kota, kepala puskesmas dan bidan harus memasukkan username dan password yang telah didaftarkan sebelumnya oleh admin. Pembatasan hak akses ini dimaksudkan agar data aman dan privasi pasien terjaga. Halaman Log in ditunjukkan gambar 2 berikut :

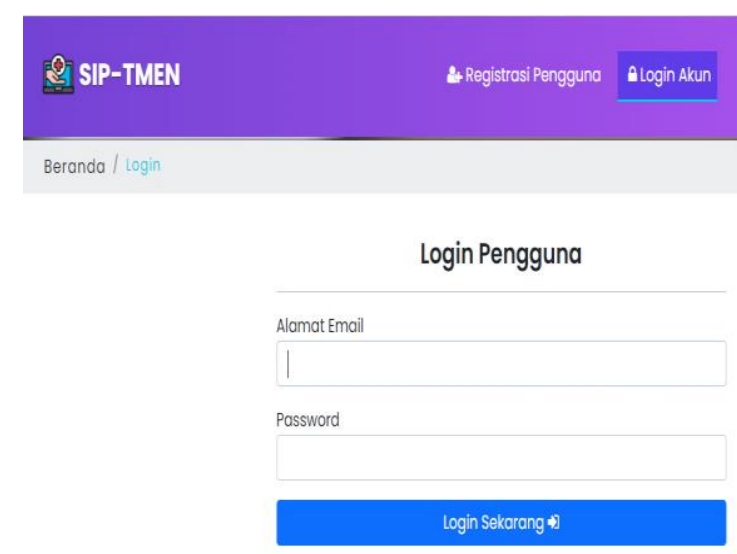

Gambar 3. Halaman Log in c. Registrasi Pengguna

Menu registrasi pengguna yaitu digunakan oleh masyarakat maupun tenaga medis untuk dapat mengakses system ini. Data yang harus di isi untuk pendaftaran adalah nama lengkap, jenis kelamin, tempat tanggal lahir, nomor telepon, golongan darah, tingkat pendidikan, pekerjaan, sttaus kawin, alamat lengkap, memilih faskes 1 seusai BPJS, alamat email dan password. Tenaga kesehatan maupun pengguna dapat melakukan edit profil pada akunnya sendiri. Secara rinci dapat dilihat pada gambar dibawah ini :

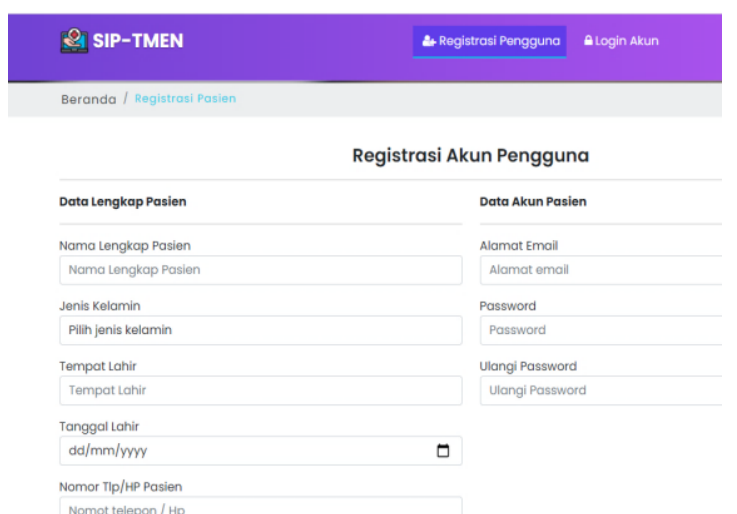

Gambar 4. Tampilan menu registrasi akun

Golongan Daran
Pilih Golongan Darah
Tingkat Pendidikan
Pilih Tingkat Pendidikan
Pekerjaan Pasien
Pilih Pekerjaan
Status kawin
Pilih status
Alamat Lengkap
Alamat Lengkap Pasien
Pilih Faskes 1 sesuai BPJS anda
APT KARYA SEHAT PROLANIS
Daftar Sekarang

Gambar 5. Lanjutan Tampilan menu registrasi akun

Untuk memudahkan pendataan dan pelaporan, masingmasing puskesmas akan dibuatkan akun admin yang dapat digunakan sebagai pemantauan serta evaluasi data. Pada menu admin akan muncul tampilan seperti dibawah ini : 


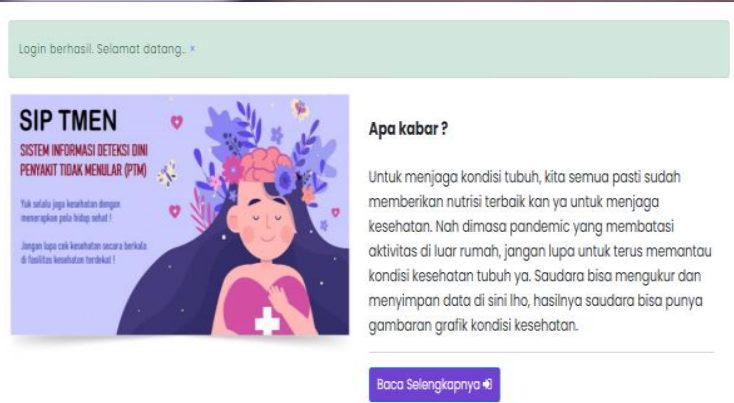

Gambar 6. Tampilan menu admin

Pada menu ini, admin dapat langsung memasukkan data klien jika ada kesulitan atau jika ada kesalahan pada saat input. Selain itu, admin juga dapat melalukan pemantauan serata pelaporan melalui akun admin. Admin merupakan perwakilan dari setiap puskesmas/posbindu baik kader maupun tenaga kesehatan. Perwakilan dari Dinas Kesehatan dalam hal ini Program Pencegahan Penyakit Tidak Menular (P2PTM) sebagai pengawas yang akan memantau jalannya laporan setiap kegiatan posbindu.

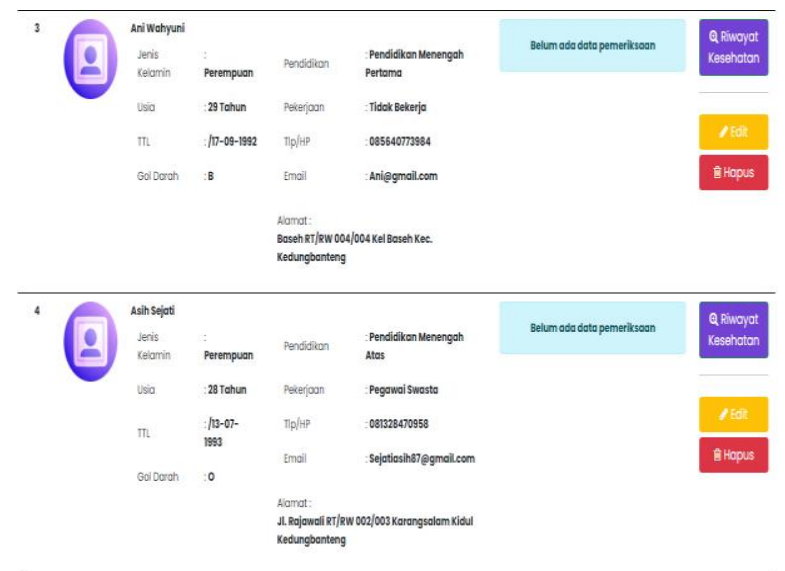

Gambar 7. Lanjutan tampilan menu admin

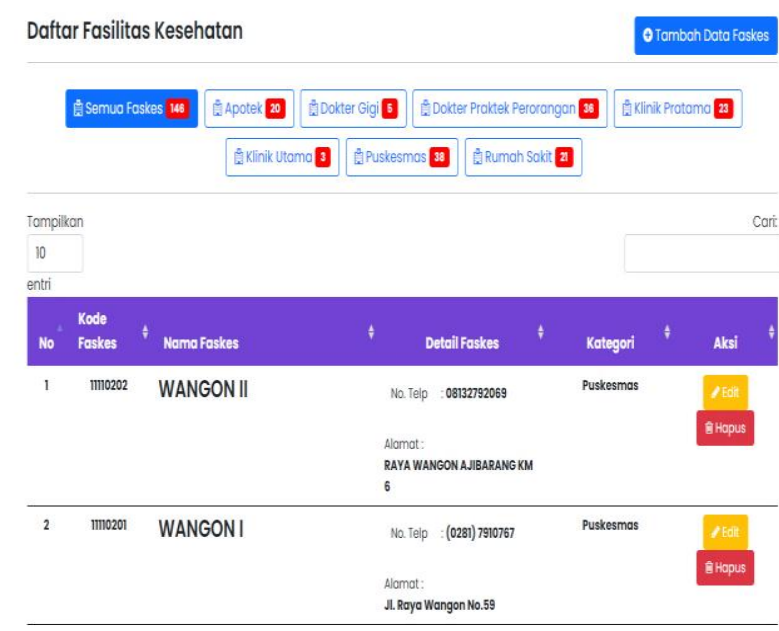

Gambar 8. Tampilan data faskes
Menu data faskes berisi data fasilitas kesehatan tingkat pertama yang ada di wilayah Banyumas. Untuk sementara data faskes yang dimasukan masih terbatas di wilayah Banyumas sesuai tempat penelitian, tidak kecil kemungkinan akan diperluas di wilayah sekitarnya. Fungsi dari menu ini adalah, jika da kegawatdaruratan atau jika hasil pemeriksaan menunjukkan rekomendasi rujukan maka sistem akan mengirim informasi kepada faskes yang dituju sesuai dengan data klien.

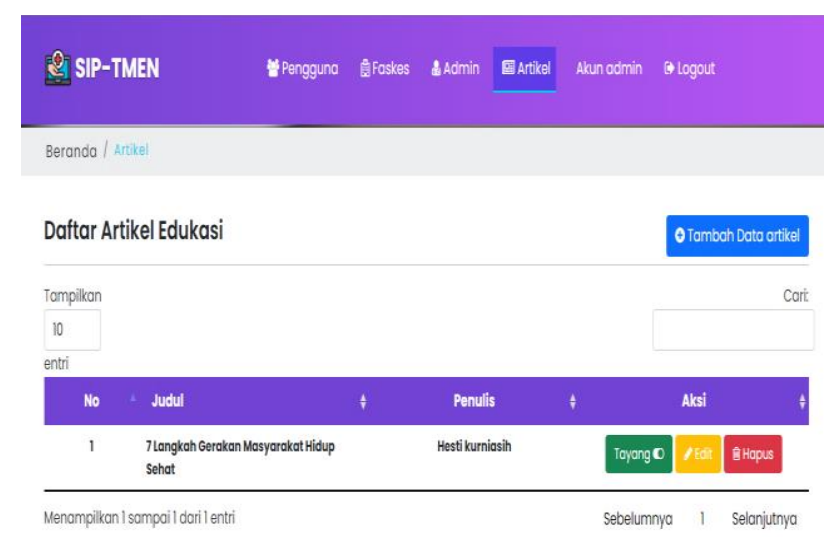

Gambar 9. Tampilan menu artikel edukasi

Menu artikel edukasi berisi tentang artikel mengenai penyakit tidak menular,pola hidup bersih dan sehat, perilaku CERDIK, program GERMAS, perilaku PATUH serta artikel-artikel yang berkaitan dengan kesehatan sesuai dengan kebutuhan klien. Admin dapat memasukkan artikel ke dalam sistem. Diharapkan dengan artikel edukasi ini, masyarakat mendapatkan informasi dalam satu genggangan serta terhindar dari informasi yang tidak sesuai dengan kaidah kesehatan maupun kedokteran.

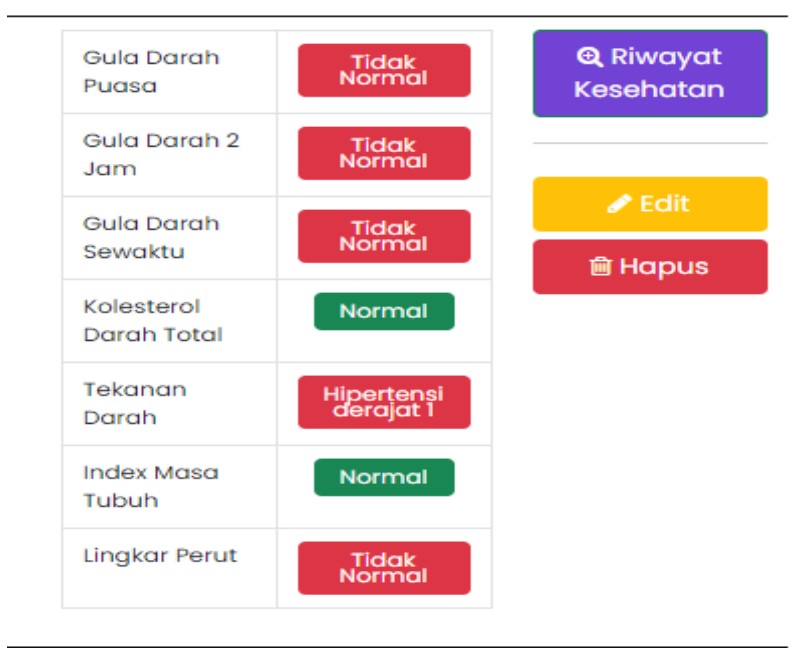

Gambar 10. Hasil analisa sistem

Setelah klien memasukkan data hasil pemeriksaan, maka sistem akan membuat kesimpulan sesuai dengan algoritma yang telah ditentukan. Sistem akan membaca setiap detail data yang dimasukan oleh klien baik data subjektif maupun objektif termasuk pemeriksaan penunjang. Hasil dari deteksi penyakit tidak menular yang dilakukan 
mandiri oleh masyarakat, akan langsung diketahui oleh tenaga kesehatan ataupun kader selaku admin/operator dalam sistem. Sehingga tenaga kesehatan dapat mengetahui kondisi masyarakat yang ada di desa nya. Penggunaan aplikasi berbasis web, mampu melaporkan risiko penyakit dengan cepat, dan mampu mengkomunikasikan hasil temuan dari pemeriksaan sehingga diharapkan penanganan dan upaya pencegahan dapat dilakukan dengan cepat dan tepat. [5]Dengan menggunakan sistem informasi ini, perawatan pasien yang selama ini dilakukan secara tradisional, dimana para tenaga kesehatan harus berada dekat dengan pasien, maka juga diharapkan upaya deteksi ini tetap bisa dilakukan walaupun tenaga kesehatan tidak secara langsung berhadapan dengan pasien.[6]

\subsection{Pembahasan}

Hasil pemantauan dari pengguna system informasi menunjukkan bahwa pengguna mampu menggunakan system informasi ini. Pengguna telah mampu melakukan pendaftaran dan menginput data yang diperlukan dalam system informasi. Data pengguna tersebut menunjukkan bahwa ada kemudahan bagi amsyarakat dalam menggunakan system infromasi berbasis web yang dibuat. System informasi dapat diakses menggunakan smartphone maupun computer. Setelah mengakses system ini pengguna dapat mengetahui status kondisi kesehatan secara langsung pengguna mampu melakukan deteksi kesehatan secara mandiri. Kondisi ini seperti dilaporkan dalam penelitian Sevani bahwa penggunaan aplikasi computer untuk deteksi dini kondisi tubuh dapat menawarkan bantuan untuk mengetahui masalah kesehatan tersebut dan secara khusus pengguna aplikasi berbasis web dapat melakukan deteksi dalam waktu yang singkat. [7]

Penggunaan aplikasi ini sangat praktis karena pengguna dapat mengakses dimana saja dan kapan saja. Berdasarkan survei pengguna internet di Indonesia telah mencapai 61 juta orang dengan durasi akses lebih dari tiga jam setiap kali penggunaan. Oleh karena itu aplikasi computer berbasis web sangat penting bagi masyarakat sebagai langkah awal monitoring dan deteksi dini status kesehatan. [8]

System informasi mampu merubah pola perawatan klien yang selama ini dilakukan secara tradisional. Mulanya para tenaga kesehatan harus berada dekat dengan pasien. Namun dengan menggunaka system informasi berbasis web upaya deteksi bisa dilaksanakan meskipun tenaga kesehatan tidak secara langsung berhadapan dengan klien menurut [6] Hal ini sangat diperlukan mengingat pada kondisi pandemic seperti saat ini sangat dibatasi kegiatan tatap muka dengan orang lain.

Semakin meningkatnya kasus penyakit tidak menular (PTM) saat ini, maka perlu ada edukasi dan pendampingan kepada masyarakat untuk mengenali penyakit tidak menular (PTM), deteksi dini penyakit tidak menular (PTM), mencegah faktor risiko penyakit tidak menular (PTM) terutama pada kelompokyang berisiko [9]. Kesadaran bagi masyarakatakan pentingnya prilaku sehat dalam mencegah penyakit tidak menular melalui GERMAS sangat diperlukan, sehingga akan menjadi salah satu cara dalam menekan angka kesakitan, khususnya penyakit tidak menular, misalnya penyakit kolesterol, diabetes melitus, danpenyakit tidak menular lainnnya [10]

Sesuai dengan teori bahwa perilaku seseorang ditentukan oleh faktor yaitu faktor predisposisi, faktor pendorong, dan faktor penguat. Pengetahuan merupakan salah satu faktor predisposisi yang mendasari perilaku seseorang untuk berperilaku positif. Pengetahuan yang baik tentang pencegahan penyakit tidak menular (PTM) dapat mempengaruhi masyarakat dalam meningkatkan kewaspadaan dini terhadap penyakit ISPA (Notoatmodjo, 2014). Peningkatan pengetahuan masyarakat tentang pencegahan penyakit tidak menular (PTM) diharapkan masyarakat sadar akan bahaya penyakit tidak menular (PTM) dengan melakukan tindakan/perilaku yang dapat mencegah penyakit tidak menular (PTM) [11]

Seperti dikatakan dalam penelitian Sevani [12] bahwa penggunaan aplikasi komputer untuk deteksi kondisi tubuh dapat menawarkan bantuan untuk mengatasi masalah kesehatan tersebut dan secara khusus bahwa penggunaan aplikasi berbasis web dapat memberikat deteksi dalam waktu yang singkat. Selain itu, penggunaan aplikasi ini praktis karena dapat diakses di mana saja dan kapan saja. Survei menjukkan bahwa pengguna internet di Indonesia telah mencapai 61 juta orang dengan durasu akses lebih dari tiga jam setiap kali penggunaan. Karena itu, aplikasi komputer sangat penting bagi masyarakat, sebagai langkah awal pencegahan penyakit [7][8]

Sistem informasi merupakan suatu solusi dari banyaknya permasalahan yang ada dalam pelayanan kesehatan seperti kurang tersedianya sumberdaya, lamanya proses pelaporan, lamanya proses administrasi, ketidaklengkapan data yang ada, keterlambatan dalam menegakkan diagnosa dan pemberian penanganan, jauhnya jarak tempuh untuk menuju tempat layanan kesehatan, mahalnya biaya transportasi menuju tempat pelayanan kesehatan dan lain sebagainya. [13][8]

\section{Kesimpulan}

Berdasarkan hasil penelitian dapat disimpulkan bahwa system informasi rule base system efektif dalam deteksi dan diagnose penyakit tidak menular. System informasi berbasis website yang dibuat dapat dimanfaatkan oleh masyarakat, penggunaan mudah, komunikatif dan informasi hasil/rekap data dapat cepat diterima

\section{Rekomendasi}

Sebagai sarana pembanding bagi dunia ilmu pengetahuan dalam memperkaya informasi tentang penyakit tidak menular, serta dilakukan uji coba dalam skala serta lingkup yang lebih luas dan konsul pakar expert terkait penentuan diagnose serta rekomendasi sesuai dengan keahlian apra pakar dalam hal ini adalah dokter spesialis. 
Perlu juga dilakukan penelitian mengenai kecepatan, ketepatan serta tingkat akurasi website serta dibuat dalam bentuk mobile aplikasi supaya masyarakat lebih mudah untuk menggunakan.

\section{Daftar Pustaka}

[1] Pusdatin Kementerian kesehatan, "Profil Kesehatan Indonesia tahun 2018," 2018. [Online]. Available:

https://pusdatin.kemkes.go.id/resources/downloa $\mathrm{d} /$ pusdatin/profil-kesehatan-

indonesia/PROFIL_KESEHATAN_2018_1.pdf.

[2] Direktorat Pencegahan dan Pengendalian Penyakit Tidak Menular, "Rencana Aksi Pengendalian Penyakit Tidak Menular," 2017.

[3] Dirjen P2PTM, Buku Pedoman Manajemen PTM. 2019.

[4] F. Purdiyani, "Pemanfaatan Pos Pembinaan Terpadu Penyakit Tidak Menular (Posbindu Ptm) Oleh Wanita Lansia Dalam Rangka Mencegah Penyakit Tidak Menular Di Wilayah Kerja Puskesmas Cilongok 1," J. Kesehat. Masy., vol. 4, no. 1, pp. 470-480, 2016.

[5] L.-E. A. Sundberg K, Wengström Y, Blomberg K, Hälleberg-Nyman M, Frank C, . "Early detection and management of symptoms using an interactive smartphone application (Interaktor) during radiotherapy for prostate cancer.," Support. Care Cancer, vol. 25(7), pp. 2195-204, 2017.

[6] D. Yuhefizar, Y., Nasution, A., Putra, R., Asri, E., \& Satria, "Alat Monitoring Detak Jantung Untuk Pasien Beresiko Berbasis IoT Memanfaatkan
Aplikasi OpenSID berbasis Web.," J. RESTI (Rekayasa Sist. dan Teknol. Informasi), vol. 3, no. 2, pp. 265-270, 2019.

[7] Y. J. Sevani, N., \& Chandra, "Web based application for early detection of vitamin and mineral deficiency.," CommIT (Communication Inf. Technol. J., vol. 10, no. 2, pp. 53-58, 2016.

[8] F. N. Aini, M. N. Widyawati, and B. Santoso, "Diagnosa Preeklampsia pada Ibu Hamil Menggunakan Sistem Informasi Berbasis Web," J. Keperawatan Silampari, vol. 2, no. 2, pp. 18-27, 2019.

[9] N. N. Warganegara, E., \& Nur, "Faktor risiko perilaku penyakit tidak menular.," J. Major, vol. 5, no. 2, pp. 88-94, 2016.

[10] Z. Yarmaliza, Y., \& Zakiyuddin, "Pencegahan Dini terhadap Penyakit Tidak Menular (PTM) melalui GERMAS.," J. Pengabdi. Masy. Multidisiplin, vol. 2, no. 3, pp. 168-175, 2019.

[11] D. A. Rofiqoch, I., \& Yuliani, "Edukasi Penyakit Tidak Menular (PTM) Dalam Rangka Pelaksanaan Germas.," in In Prosiding Seminar Nasional LPPM UMP, 2019, p. pp 73-76.

[12] C. Y. Sevani N, "Web Based Application for Early Detection of Vitamin and Mineral Deficiency," CommIT (Communication Inf. Technol. J., vol. 10(2), no. 53-8, 2016.

[13] et al. Wan S-X, Li H-L, Wang W, Shen Q, Li CH, Lyon ME, "Psychometric Properties Of The Postpartum Women Health Quotient Scale Among Chinese Post Partum Women. Midwifery," Suppl. C, vol. 39, pp. 63-70, 2016. 